\title{
Effect of the Chemical Composition on the Structural State and Mechanical Properties of Complex Microalloyed Steels of the Ferritic Class
}

\author{
Alexander Zaitsev ${ }^{1,2}$, Anton Koldaev ${ }^{1}$, Nataliya Arutyunyan 1,2,*, Sergey Dunaev ${ }^{2}$ and \\ Dmitrii D'yakonov ${ }^{1}$ \\ 1 Bardin Central Research Institute of Ferrous Metallurgy, Moscow 105005, Russia; \\ aizaitsev1@yandex.ru (A.Z.); koldaevanton@gmail.com (A.K.); aberkas@yandex.ru (D.D.) \\ 2 Faculty of Chemistry, Lomonosov Moscow State University, Moscow 119991, Russia; \\ dunaev@general.chem.msu.ru \\ * Correspondence: naarutyunyan@gmail.com; Tel.: +7-495-939-1673
}

Received: 28 April 2020; Accepted: 27 May 2020; Published: 29 May 2020

\begin{abstract}
The most promising direction for obtaining a unique combination of difficult-to-combine properties of low-carbon steels is the formation of a dispersed ferrite microstructure and a volumetric system of nanoscale phase precipitates. This study was aimed at establishing the special features of the composition influence on the characteristics of the microstructure, phase precipitates, and mechanical properties of hot-rolled steels of the ferritic class. It was carried out by transmission electron microscopy and testing the mechanical properties of metal using 8 laboratory melts of low-carbon steels microalloyed by $\mathrm{V}, \mathrm{Nb}, \mathrm{Ti}$, and $\mathrm{Mo}$ in various combinations. It was found that block ferrite prevails in the structure of steel cooled after hot rolling at a rate of $10-15^{\circ} \mathrm{C} / \mathrm{s}$. Lowering of the microalloying components content leads to a decrease in the block ferrite fraction to 20-35\% and the dominance of polygonal ferrite. The presence of nanoscale carbide (carbonitride) precipitates of austenitic and interphase/mixed types was detected in the rolled steels. It was established that the tendencies of changes in the characteristics of the structural state and present phase precipitates correlate well with obtained values of strength properties. The advantages of titanium-based microalloying systems in comparison with vanadium-based are shown.
\end{abstract}

Keywords: low-carbon steels of the ferritic class; nanoscale phase precipitates; strength characteristics; steel composition; hot rolling; structure

\section{Introduction}

Currently, research and development of new types of structural steels is preferably aimed at achieving simultaneously high indicators of difficult-to-combine properties: strength, ductility, formability, corrosion resistance, weldability, and other service characteristics while reducing production costs [1]. This is due to an increase in requirements for critical parts used in various branches of engineering and industry: construction, engineering, transport, mining, oil, and others. The use of traditional methods for increasing the strength of steel, which are based on the implementation of such hardening mechanisms as grain boundary, solid solution, and dispersion hardening, causes a deterioration in ductility and other service properties. The search for fundamentally new solutions has led to the development of advanced steels for automobile sheet: dual-phase ferrite-martensitic and multiphase steels with complex phase composition, as well as with increased ductility achieved as a result of effects of transformation- and twinning-induced plasticity [1,2]. However, such steels, due to the presence of hard components (martensite, bainite, etc.) in their structure, have limited formability, and their production requires the use of specialized equipment and a complex alloying system, leading 
to increased costs [2]. Thus, to date, there are no steels combining simultaneously high indicators of strength, ductility, formability, fatigue and corrosion resistance, and other service properties.

The most promising direction for solving the formulated problem is the creation of new steels with a homogeneous ductile ferrite microstructure strengthened by formation of a volumetric system of nanoscale phase precipitates and ferrite grain refinement [3-9]. Both strengthening mechanisms, in many respects, are controlled by phase precipitations of various types and dispersion. The precipitates formed in austenite (austenitic) contribute to the refinement of the microstructure. The dispersion hardening mechanism is realized mainly due to the precipitation of carbides and carbonitrides during or after the $\gamma \rightarrow \alpha$ phase transformation when steel is cooling or tempering [3,10,11]. Such precipitates are named interphase and ferritic, respectively. Interphase precipitates, as a rule, have a size of 1-5 nm. They are arranged in layers with a period of $10-50 \mathrm{~nm}$, parallel to the moving front of the $\gamma / \alpha$ transformation. In ferrite, disordered formation of nanoscale carbide (carbonitride) precipitates occurs. Their nucleation and growth takes place at dislocations; the average size, as a rule, is 3-10 $\mathrm{nm}$ [10].

Initially, to follow these principles, the Ti-Mo microalloying system was used, which provided producing rolled products with a strength of up to 700-1000 $\mathrm{MPa}$ and high ductility, formability, and other properties [4,12-14]. It was established that the formation of interphase precipitates, which make a greater contribution to the strengthening than ferritic, occurs at a low $\left(10-15^{\circ} \mathrm{C} / \mathrm{s}\right)$ cooling rate of steel after rolling, leading to the simultaneous formation of a polygonal ferrite structure with reduced strength characteristics [4]. Obtaining a stronger high-dislocation structure of block (acicular) ferrite is the result of a higher $\left(\sim 30^{\circ} \mathrm{C} / \mathrm{s}\right)$ metal cooling rate, causing phase precipitation in ferrite. Maximum strength indicators can be achieved by creating conditions for the simultaneous formation of an acicular ferrite structure and a system of nanoscale interphase precipitates [4,5].

The results of subsequent studies (e.g., $[6,15]$ ) showed the possibility of using more complex $\mathrm{V}-\mathrm{Nb}$-Ti-Mo microalloying systems. It served as the basis for the development of technologies for the production of hot-rolled XPF650, XPF800, and XPF1000 steels of 650-1000 MPa strength classes at TATA steel (UK, Netherlands) [7]. However, they are characterized by a high content of manganese and microalloying components (up to wt.\%): Mn-2, V-0.32, Nb-0.08, Mo-0.50, and the technological parameters of production are mainly established by trial and error. This is due to the lack of reliable data on the tendencies of the effect of the composition on the characteristics of forming phase precipitates, the structural state, and mechanical properties of complex microalloyed steels of the ferritic class. The present study aims to establish these influence patterns.

\section{Materials and Methods}

The investigation was carried out for low-carbon steels of the ferritic class, microalloyed by $\mathrm{V}, \mathrm{Nb}$, $\mathrm{Ti}$, and Mo in various combinations close to XPF grade. The steels were smelted in a vacuum induction furnace with a magnesite crucible with a steel capacity of 7-8 kg and casted in a heated mold in one ingot. The chemical composition (Table 1) of the investigated steels was obtained by spectral analysis using an emission spectrometer.

Table 1. The chemical composition of the studied steels, wt.\%.

\begin{tabular}{cccccccccccc}
\hline No. Steel & $\mathbf{C}$ & $\mathbf{S i}$ & $\mathbf{M n}$ & $\mathbf{P}$ & $\mathbf{S}$ & $\mathbf{M o}$ & $\mathbf{A l}$ & $\mathbf{T i}$ & $\mathbf{N b}$ & $\mathbf{V}$ & $\mathbf{N}$ \\
\hline 1 & 0.059 & 0.135 & 1.23 & 0.002 & 0.004 & 0.005 & 0.036 & 0.070 & 0.110 & - & 0.0070 \\
2 & 0.053 & 0.110 & 1.28 & 0.003 & 0.004 & - & 0.020 & 0.078 & 0.030 & - & 0.0075 \\
3 & 0.059 & 0.150 & 1.36 & 0.002 & 0.004 & - & 0.031 & 0.110 & 0.027 & - & 0.0115 \\
4 & 0.061 & 0.150 & 1.38 & 0.003 & 0.004 & 0.200 & 0.020 & 0.170 & 0.024 & - & 0.0097 \\
5 & 0.053 & 0.110 & 1.50 & 0.003 & 0.005 & 0.210 & 0.011 & 0.069 & 0.010 & 0.005 & 0.0091 \\
6 & 0.050 & 0.087 & 1.47 & 0.003 & 0.005 & 0.190 & 0.017 & 0.068 & 0.010 & 0.200 & 0.0135 \\
7 & 0.048 & 0.093 & 1.55 & 0.003 & 0.003 & 0.190 & 0.016 & 0.100 & 0.015 & 0.010 & 0.0076 \\
8 & 0.055 & 0.088 & 1.60 & 0.003 & 0.006 & 0.200 & 0.019 & 0.130 & 0.016 & 0.059 & 0.0083 \\
\hline
\end{tabular}


It is seen from Table 1 that the produced steels are characterized by a relatively high manganese content of 1.2-1.6 wt.\%, as well as by a complex system of separate or joint microalloying of $\mathrm{V}, \mathrm{Nb}, \mathrm{Ti}$, and Mo with a variation in the concentrations of the components over a relatively wide range. Due to the special feature of laboratory smelting, the produced steels have a relatively high nitrogen content and low phosphorus concentration. As will be shown below, this imposes a certain physical reserve on the established mechanical properties of rolled products due to the negative influence of nitrogen and neutral effect of phosphorus [16]. The steel ingots of all compositions were heated to $1250{ }^{\circ} \mathrm{C}$ and rolled on a DUO-300 reversible rolling mill into strips of $3 \mathrm{~mm}$ thick with a rolling end temperature of $900 \pm 15^{\circ} \mathrm{C}$. After the rolling end, the strip was cooled in an air stream with a cooling rate of $10-15^{\circ} \mathrm{C} / \mathrm{s}$ to $650{ }^{\circ} \mathrm{C}$. This temperature was chosen based on the previously obtained evidence [17] that to increase the strength properties, it is necessary to use relatively high temperatures for coiling the strip. Then, the strip was placed in a furnace heated to $650{ }^{\circ} \mathrm{C}$, kept for $30 \mathrm{~min}$, followed by cooling with the furnace, simulating the cooling of a roll. Samples were made from the obtained hot-rolled strips.

The microstructure was studied by scanning electron microscopy, SEM, using a JSM-6610LV (JEOL) device equipped with an INCA Energy Feature XT energy dispersive microanalysis system, INCA Wave 500 wave dispersion spectrometer, and transmission electron microscopy, TEM, using a JEM200CX device. Due to big difference between dislocations density in different ferrite types, it was determined by counting dislocations on TEM images related to each type. The type of nanoscale precipitates was identified using the original technique based on analysis of their reflexes on microdiffraction images and a comparison of several characteristics, including the following. Austenitic precipitates always have a tangential scatter of reflexes on microdiffraction images, which means disorientation of the particles, sometimes quite substantial (several degrees). Reflexes from ferritic particles look like long radial bands. Interphase precipitates usually have superposition of both special characteristics of reflexes. The common distinguishing feature of interphase precipitates is their arrangement in layers parallel to the moving front of the $\gamma / \alpha$ transformation. Particles formed in austenite are characterized by the same orientation of particles in neighboring ferrite grains with different orientations. Another indicator is the Baker-Nutting orientation relationship for precipitates and the ferrite matrix. This relation occurs for ferritic particles, for austenitic —it is not fulfilled, and interphase precipitates have only one orientation relationship [18].

The mechanical properties (yield strength, ultimate tensile strength, and relative elongation) were determined using a HECKERT FP-100/1 tensile testing machine.

The thermodynamic analysis of the regions of phases existence in the studied steels was carried out using the thermodynamic computer model [19] implemented on the basis of proprietary software, by finding the conditions of thermodynamic equilibrium in multicomponent, multiphase systems with given external and internal parameters (temperature, pressure, chemical composition). As a result, the types of equilibrium phases, their quantities and compositions were determined by analysis of the complete possible set for an alloying system of steel under consideration.

\section{Results}

The results of determining the mechanical properties of the samples of investigated rolled steels are presented in Table 2.

Table 2. Mechanical properties of the studied rolled samples.

\begin{tabular}{cccc}
\hline No. Steel & Yield Strength, MPa & Ultimate Tensile Strength, MPa & Relative Elongation, $\%$ \\
\hline 1 & 615 & 680 & 15 \\
2 & 535 & 600 & 18 \\
3 & 585 & 655 & 16 \\
4 & 650 & 765 & 15 \\
5 & 555 & 625 & 15 \\
6 & 610 & 700 & 14 \\
7 & 605 & 665 & 16 \\
8 & 600 & 700 & 12 \\
\hline
\end{tabular}


As can be seen from Table 2, the strength characteristics of the rolled samples vary over a wide range, rising with increasing in $\mathrm{V}, \mathrm{Nb}$, and $\mathrm{Ti}$ concentrations and when $\mathrm{Mo}$ is present in the steel composition. The values of relative elongation have close values in the absence of a definite correlation with the strength characteristics. To clarify the noted features of the behavior of mechanical properties, a study was carried out of structural state characteristics and present phase precipitates in rolled steels.

By means of SEM, it was found that all studied samples have a close ferrite microstructure. To establish the mechanisms of the influence of chemical composition on the structure formation and properties of the steels under investigation, a detailed study of their structural state and the carbide (carbonitride) precipitates present was made by TEM methods. The results are summarized in Table 3. In all cases, similar tendencies have been established for rolled steels containing $\mathrm{Nb}, \mathrm{Ti}$, and for steels of $\mathrm{V}, \mathrm{Nb}, \mathrm{Ti}$, and Mo complex microalloying. It was found that the metal matrix of rolled samples from steels of all melts consists of ferrite of two morphological types: block and polygonal. Block ferrite, BF, (Figure 1) is characterized by a dislocation density ranging from medium to high. The shape of the blocks is close to equiaxed. The elongated shape of the blocks in the rolled steels No. 1, 2, 3 was not found, in samples of steels containing molybdenum, except steel No. 6-was rarely observed. In rolled steel of smelting No. 6, the shape of ferrite blocks is predominantly elongated and rarely close to equiaxial.

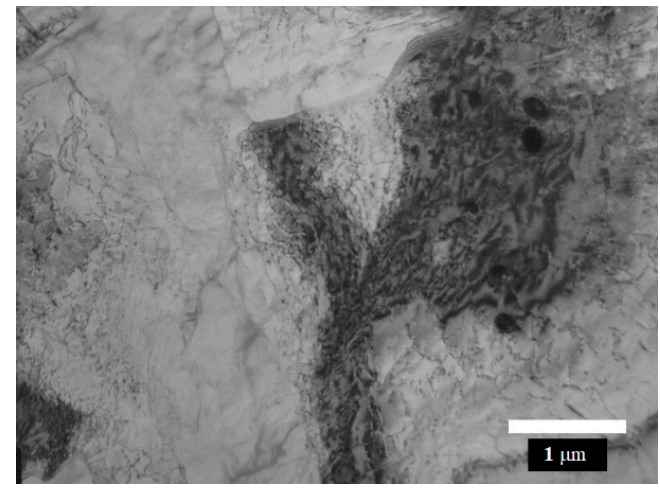

(a)

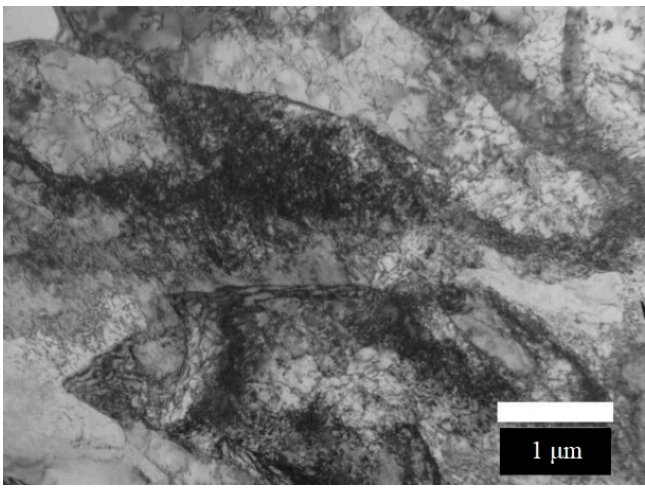

(b)

Figure 1. Typical views of block ferrite in rolled steel of smelting: (a)—No. 1, (b)—No. 6, ×15,000.

Polygonal ferrite, PF, (Figure 2a) has dislocation density varying from low to medium, grain size, as a rule-up to 10-15 $\mu \mathrm{m}$. In some cases (melts No. 2,3,5), there are separate grains larger than $15 \mu \mathrm{m}$. In all steels, except No. 2 and 3, the volume fraction of block ferrite is predominant. In rolled steel No. 1, rarely located regions of quasipolygonal ferrite are also detected (Figure 2b) with developed blocking and dislocation density, which is intermediate between that characteristics for PF and BF.

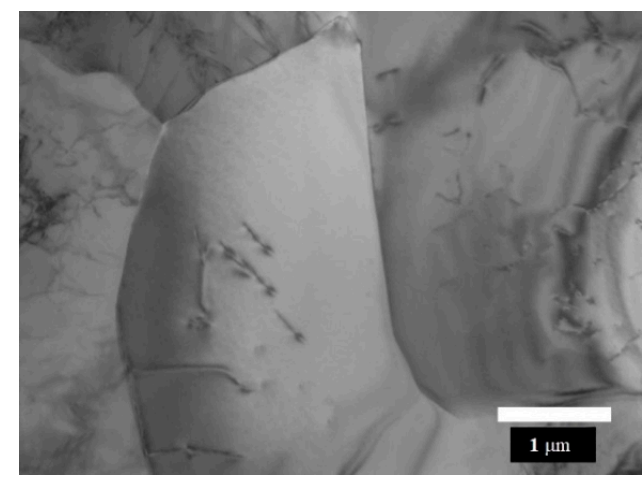

(a)

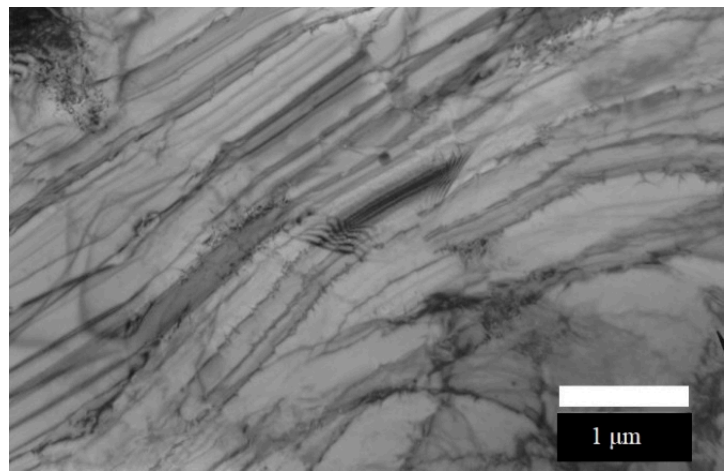

(b)

Figure 2. Typical views of polygonal (a) and quasipolygonal (b) ferrite in rolled steel of smelting No. 1, $\times 15,000$. 
Table 3. A summary of the results of the microstructure and phase precipitates investigation of the studied steels.

\begin{tabular}{|c|c|c|c|c|c|c|c|c|c|c|}
\hline \multirow{3}{*}{$\begin{array}{l}\text { No. } \\
\text { Steel }\end{array}$} & \multicolumn{6}{|c|}{ Characteristics of Microstructure } & \multicolumn{4}{|c|}{ Characteristics of Precipitates } \\
\hline & \multicolumn{3}{|c|}{ Block Ferrite } & \multicolumn{2}{|c|}{ Polygonal Ferrite } & \multirow[b]{2}{*}{$\begin{array}{l}\text { Cementite, } \\
\text { Amount/size }\end{array}$} & \multicolumn{2}{|c|}{ Austenitic } & \multicolumn{2}{|c|}{ Interphase } \\
\hline & Fraction, \% & Form & $\begin{array}{c}\text { Dislocations } \\
\text { Density, } \text { cm }^{-2}\end{array}$ & $\begin{array}{c}\text { Dislocations } \\
\text { Density, } \mathrm{cm}^{-2}\end{array}$ & $\begin{array}{c}\text { Grain Size, } \\
\mu \mathrm{m}\end{array}$ & & $\begin{array}{c}\text { Grain } \\
\text { Fraction, \% }\end{array}$ & $\begin{array}{l}\text { Size, nm } \\
\text { Length/ } \\
\text { Width }\end{array}$ & $\begin{array}{c}\text { Grain Amount/ } \\
\text { Amount in a } \\
\text { Grain }\end{array}$ & Size, nm \\
\hline 1 & $65-75$ & Equiaxed & $\sim 6 \times 10^{10}$ & $\sim 3 \times 10^{9}$ & $\begin{array}{l}\text { Up to } \\
10-15\end{array}$ & $\begin{array}{c}\text { Few/ } \\
\text { several } \mu \mathrm{m}\end{array}$ & 20 & $10 /$ up to $3-4$ & $\begin{array}{c}\text { In almost all } \\
\text { grains/ significant }\end{array}$ & $\begin{array}{l}\text { Up to } 3-4 \text {, rarely } \\
\text { up to } 5-6\end{array}$ \\
\hline 2 & $25-35$ & Equiaxed & $\sim 2 \times 10^{10}$ & $\sim 3 \times 10^{9}$ & $\begin{array}{c}10-15 \\
\text { there are }>15\end{array}$ & $\begin{array}{c}\text { Few/ } \\
\text { several } \mu \mathrm{m}\end{array}$ & $15-20$ & $10 / 3-4$ & $\begin{array}{c}\text { In almost all } \\
\text { grains/less than in } \\
\text { steel No } 3\end{array}$ & $\begin{array}{l}\text { Up to } 3-4 \text {, rarely } \\
\text { up to } 5-6\end{array}$ \\
\hline 3 & $20-30$ & Equiaxed & $\sim 2 \times 10^{10}$ & $\sim 3 \times 10^{9}$ & $\begin{array}{c}10-15 \\
\text { there are }>15\end{array}$ & $\begin{array}{c}\text { Few/ } \\
\text { several } \mu \mathrm{m}\end{array}$ & $15-20$ & $10 / 3-4$ & $\begin{array}{l}\text { In almost all } \\
\text { grains/less than in } \\
\text { steel No } 1\end{array}$ & $\begin{array}{l}\text { Up to } 3-4 \text {, rarely } \\
\text { up to 5-6 }\end{array}$ \\
\hline 4 & $60-80$ & $\begin{array}{c}\text { Equiaxed, rarely } \\
\text {-elongated }\end{array}$ & $\sim 6 \times 10^{10}$ & $\sim 3 \times 10^{9}$ & $\begin{array}{l}\text { Up to } \\
10-15\end{array}$ & No & 50 & $\begin{array}{l}\text { Up to } 15 / \\
\text { up to } 3-4\end{array}$ & $\begin{array}{c}\text { In all grains/ } \\
\text { significant }\end{array}$ & Up to $2-4$ \\
\hline 5 & $80-85$ & $\begin{array}{l}\text { Equiaxed, rarely } \\
\text {-elongated }\end{array}$ & $\sim 2 \times 10^{10}$ & $\sim 3 \times 10^{9}$ & $\begin{array}{c}10-15 \\
\text { there are }>15\end{array}$ & $\begin{array}{c}\text { Few/ } \\
\text { several } \mu \mathrm{m}\end{array}$ & 10 & $\begin{array}{l}\text { Up to } 10 / \\
\text { up to } 3-4\end{array}$ & Rarely/a few & Up to $3-4$ \\
\hline 6 & 90 & Elongated & $\sim 2 \times 10^{10}$ & $\sim 1 \times 10^{9}$ & $\begin{array}{l}\text { Up to } \\
10\end{array}$ & No & 75 & $\begin{array}{l}\text { Up to } 15 / \\
\text { up to } 3-4\end{array}$ & $\begin{array}{c}\text { In all grains/ } \\
\text { significant }\end{array}$ & Up to $3-4$ \\
\hline 7 & $80-85$ & $\begin{array}{l}\text { Equiaxed, rarely } \\
\text {-elongated }\end{array}$ & $\sim 6 \times 10^{10}$ & $\sim 3 \times 10^{9}$ & $\begin{array}{l}\text { Up to } \\
10-15\end{array}$ & $\begin{array}{c}\text { Few/BF: } \\
<0.2-0.3 \mu \mathrm{m}, \\
\text { PF: up to } 1 \mu \mathrm{m}\end{array}$ & 50 & $\begin{array}{l}\text { Up to } 10 / \\
\text { up to } 3-4\end{array}$ & $\begin{array}{c}\text { In all grains/ } \\
\text { significant }\end{array}$ & Up to $2-4$ \\
\hline 8 & $85-90$ & $\begin{array}{l}\text { Equiaxed, rarely } \\
\text {-elongated }\end{array}$ & $\sim 6 \times 10^{10}$ & $\sim 1 \times 10^{9}$ & $\begin{array}{l}\text { Up to } \\
10\end{array}$ & No & 60 & $\begin{array}{l}\text { Up to } 10 / \\
\text { up to } 3-4\end{array}$ & $\begin{array}{l}\text { In all grains/ } \\
\text { significant }\end{array}$ & Up to $2-4$ \\
\hline
\end{tabular}


By means of TEM study of thin foils, the presence of austenite in the rolled structure of all the studied steels was not detected. In all melts, with the exception of No. 4, 6, 8, a small amount of cementite was detected. It has the form of separate precipitates along the boundaries of grains/blocks with sizes up to several micrometers (Figure 3). Precipitates of smaller sizes $\sim 0.1-0.2 \mu \mathrm{m}$ are practically absent. Cementite precipitates were not found in rolled steel from smelting No. 6, and in the case of smelting No. 7, their size in BF was, as a rule, no more than $0.2-0.3 \mu \mathrm{m}$, and in PF-up to $\sim 1 \mu \mathrm{m}$.

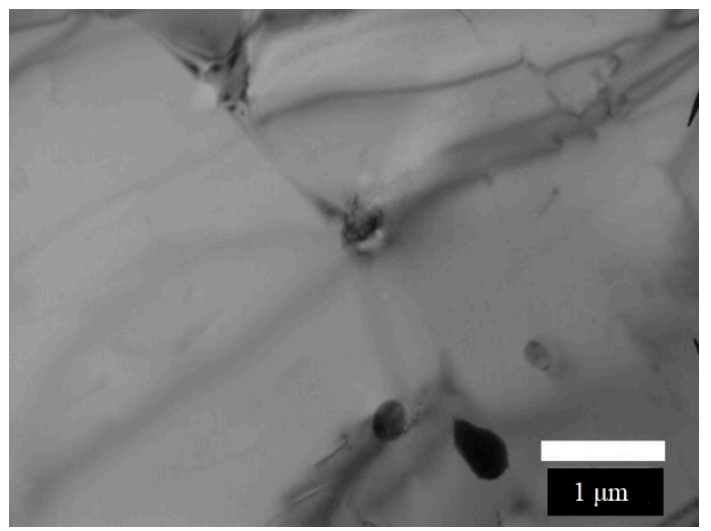

Figure 3. Typical view of cementite precipitate in rolled steel of smelting No. 2, $\times 15,000$.

Detected nanoscale carbide, carbonitride precipitates belong to two dimensional types. The first type includes elongated austenitic precipitates up to $\sim 10 \mathrm{~nm}$ in length (in the case of smelting No. 4, 6-up to $\sim 15 \mathrm{~nm}$ ) and not more than 3-4 nm in width (Figure $4 \mathrm{a}$ ) formed in austenite. In the case of steels No. 1, 2, 3, they were searched out in approximately 15-20\% of ferrite grains, which have a favorable orientation for their detection. Herewith, in those grains/blocks, in which they are present, their number is usually small. In the case of smelting No. 4, 6, 7, and 8, austenitic precipitates are significantly more representative and are found out in about $50-75 \%$ of ferrite grains, which have a favorable orientation for their detection. The minimum amount of austenitic precipitates was observed in steel No. 5 .

Another size group consists of nanoscale precipitates of interphase/mixed type, which are systematically present both in grains/blocks, in which austenitic precipitates are present, and in grains/blocks, in which they are absent (Figure 4b). Except for steel No. 5, apparently, interphase precipitates are localized in almost all ferrite grains/blocks. The size of precipitates observed in most sections is up to 3-4 $\mathrm{nm}$. Regions where interphase precipitates are larger-up to 5-6 nm are rarely found. For interphase precipitates, the reflexes are noticeably blurred in the tangential direction. Reflexes of complex shape correspond to nanoscale precipitates of a mixed type. Diffraction patterns, in which reflexes from nanoscale precipitates would have the shape of a radially elongated strand (i.e., precipitates would form mainly in ferrite), were not detected.

The results of TEM analysis of carbide precipitates amounts can be explained using thermodynamic calculation of the temperature dependences of the equilibrium phase composition of studied steels. They are presented at Figure 5 for melts No. 2 and 4, which are characterized by minimum and maximum strength properties, respectively. The fraction of titanium-based complex carbide in austenite and ferrite in steel No. 4 is higher. This is consistent with TEM results of nanoscale precipitates (Table 3). In addition, $(\mathrm{Ti}, \mathrm{Nb}) \mathrm{C}$ formation in steel No. 4 occurs at a higher temperature. Therefore, for this steel, a greater degree of realization of grain refinement should be expected due to the inhibition of austenite recrystallization caused by the deformation-initiated formation of precipitates, which is observed experimentally. The conditions for the formation of $\mathrm{Fe}_{3} \mathrm{C}$, a complex $\mathrm{Fe}_{7} \mathrm{C}_{3}$-based carbide, and $\mathrm{Mo}_{2} \mathrm{C}$ occur at temperatures below $700{ }^{\circ} \mathrm{C}$. As a result of the diffusion inhibition and the consumption of a significant amount of carbon for the complex titanium-based carbide precipitation, the formation of cementite, molybdenum carbide, and complex iron carbide $\mathrm{M}_{7} \mathrm{C}_{3}$ is almost completely suppressed. 


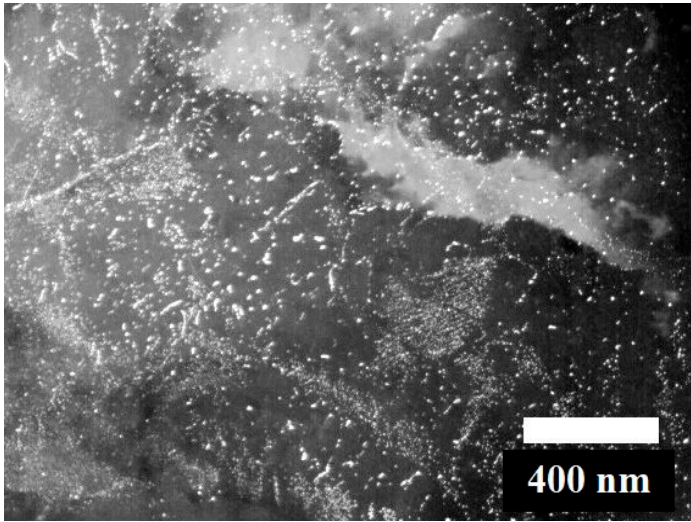

(a)

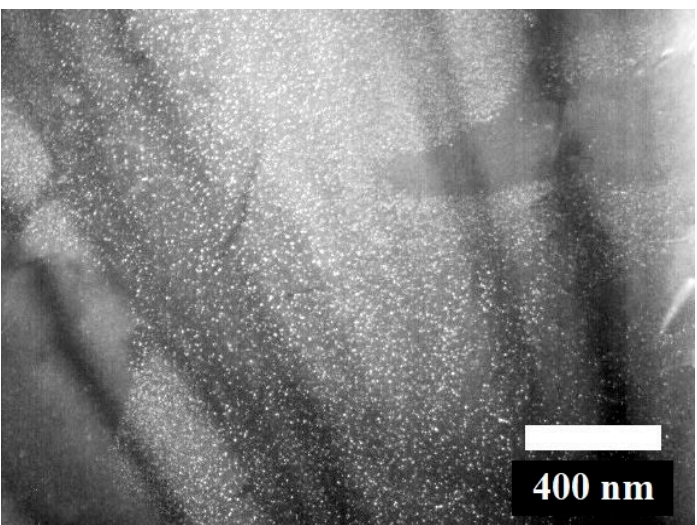

(c)

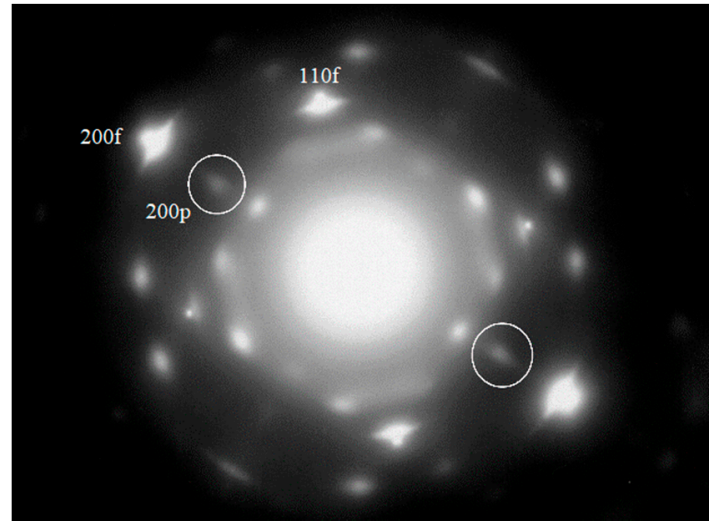

(b)

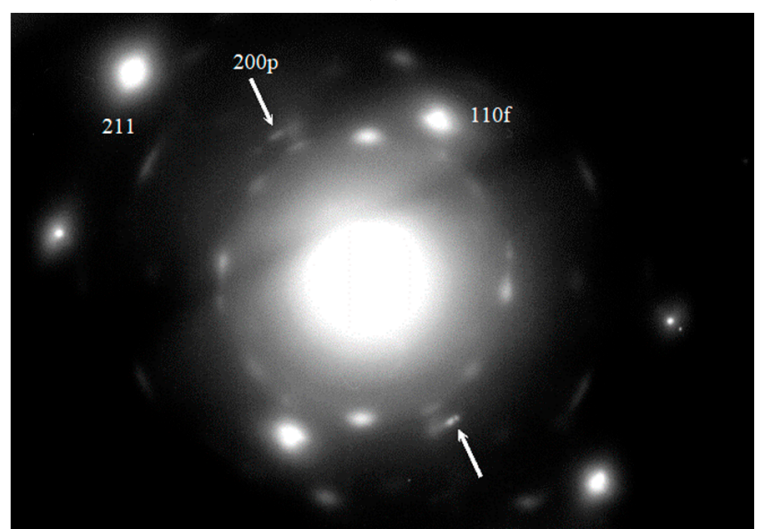

(d)

Figure 4. Typical dark-field and microdiffraction images of austenitic precipitates in rolled steel of smelting No. $6(\mathbf{a}, \mathbf{b})$ and interphase precipitates in rolled steel of smelting No. 2 (c,d): $(\mathbf{a}, \mathbf{c})$-dark-field images, $\times 30,000,(\mathbf{b}, \mathbf{d})$ - microdiffraction images.

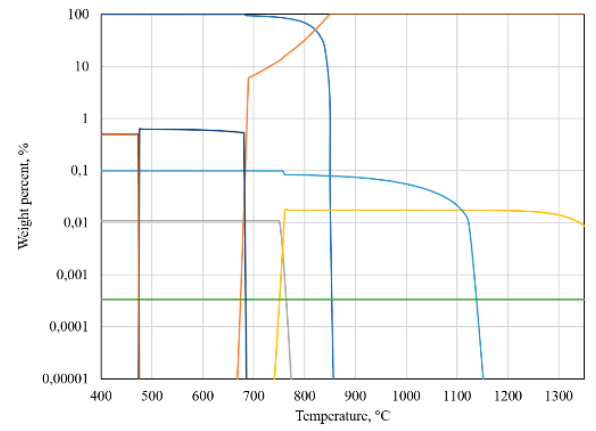

(a)

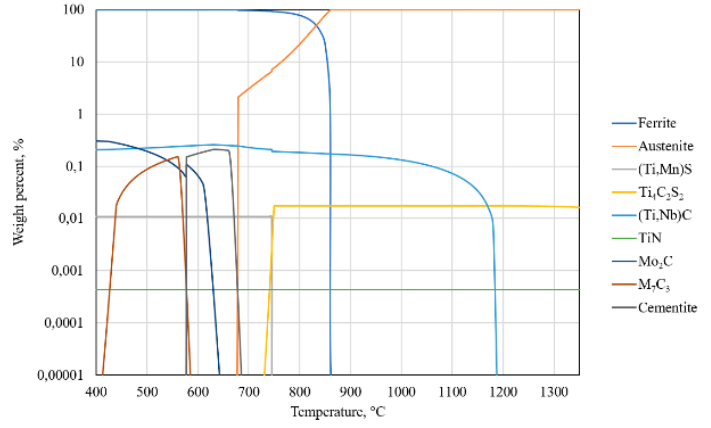

(b)

Figure 5. Temperature dependences of equilibrium fractions of phases in steels No. 2 (a) and 4 (b). $\mathrm{M}_{7} \mathrm{C}_{3}$ is a complex $\mathrm{Fe}_{7} \mathrm{C}_{3}$-based carbide.

\section{Discussion}

The results of the present study indicate that the microstructure of complex microalloyed steels of the ferritic class differ from the special features of Ti-Mo steels structure formation. Even at a low cooling rate after the rolling end $-10-15{ }^{\circ} \mathrm{C} / \mathrm{s}$, block ferrite is formed mainly, although the shape of the blocks is closer to equiaxed, with the exception of smelting No. 6, where the blocks are elongated. Only in rolled products of smelting No. 2, 3 the fraction of PF prevails over share of block ferrite, as in Ti-Mo microalloyed steels $[5,20]$. This, most likely, is associated with a low content of microalloying elements in the steels under consideration relative to other compositions, including 
the absence of molybdenum. According to [21], the addition of molybdenum to niobium-containing steels with a manganese content of up to $\sim 1.5 \mathrm{wt}$ \% $\%$ promotes obtaining of a homogeneous structure of block (acicular) ferrite. It should be noted that microalloying with molybdenum also affects the formation of nanoscale carbide precipitates: their number increases and their size decreases. This is confirmed by a series of studies of steels with different base microalloying components and their combinations [10,22-26]. The favorable effect of molybdenum is explained in $[20,27]$ by the fact that this element can suppress the annihilation of dislocations at high temperature and provide a larger number of carbide nucleation centers. In addition, there is an acceleration of the process of formation of precipitations. According to [20], the incorporation of molybdenum into carbide during the formation of complex precipitates reduces the degree of mismatch between the lattices of the carbide and the matrix due to a decrease in the lattice period, and, consequently, the energy of the carbide/austenite interface. The effect of molybdenum observed in this study is completely consistent with the foregoing.

The amount of austenitic precipitates in steels No. 1, 2, 3 is relatively small compared to Mo microalloyed steels, despite the close carbon content and high $\mathrm{Nb}$ concentration $-0.11 \mathrm{wt} \%$ in the smelting metal No. 1. In samples of steels containing molybdenum, except steel No. 5, a significant amount of austenitic carbide (carbonitride) precipitates of complex composition containing $\mathrm{Nb}$ and $\mathrm{V}$ is formed, which is consistent with the data of $[23,28]$. The number of such precipitates in rolled steel No. 6 is well over due to a significantly higher concentration of vanadium, and in steel of smelting No. 4-titanium. However, the influence of austenitic precipitates on the formation of the structural state and properties of the studied steels is apparently insignificant, since the size of the ferrite grain is in all cases close and, as a rule, is less than 10-15 $\mu \mathrm{m}$. Only in the case of rolled steels of melts No. 2, 3, 5 in some samples there are grains larger than $15 \mu \mathrm{m}$. On the other hand, the amounts of austenitic precipitates detected in steels No. 1, 2, 3 are rather close. Higher strength characteristics and a smaller grain size of rolled steel No. 1 compared to No. 2, most likely, is associated with the inhibition of recrystallization during hot rolling by niobium in solid solution [29], as well as grain refinement during the formation of interphase precipitates [30]. The number of such precipitates in rolled products of steel No. 1 is greater due to higher $\mathrm{Nb}$ and $\mathrm{C}$ concentrations, low $\mathrm{N}$ content and is comparable with this indicator for steels No. 4,6, 7, 8. This is associated with a significant consumption of microalloying elements, especially in the case of smelting No. 6 , for the formation of carbide (carbonitride) precipitates in austenite.

The established special features of changes in the characteristics of the structural state and present phase precipitates have a good correlation with the obtained values of the mechanical properties (Table 2). Rolled steels of smelting No. 1, 6, 7, 8 are characterized by similar strength characteristics. Slightly lower values in the case of smelting No. 2, 3, 5, most likely, are associated with slightly coarser microstructure and fewer interphase precipitates controlling the dispersion hardening. The highest yield and tensile strength were obtained for hot-rolled steel of smelting No. 6 having a complex microalloying system of $\mathrm{V}, \mathrm{Nb}, \mathrm{Ti}$, and Mo. The presence of high concentrations of $\mathrm{V}, \mathrm{Mo}$ and an increased Mn content facilitates the transformation of austenite to BF even at a low cooling rate, leading to the formation of an elongated shape of blocks and creates the conditions for the formation of a large number of austenitic and interphase precipitates based on $\mathrm{V}(\mathrm{C}, \mathrm{N})[21,28]$. This is in good agreement with the results of $[7,23]$, which showed that a significant contribution to hardening is achieved due to the large number of nanoscale precipitates of vanadium carbide (carbonitride). In this case, a further increase in strength properties is possible with an increase in the cooling rate and carbon content in steel. When a high cooling rate after hot rolling of $50{ }^{\circ} \mathrm{C} / \mathrm{s}$ was used in [7], the tensile strength of steel with the composition (wt.\%): 0.05C-1.7Mn-0.06Nb-0.15Mo-0.22V was $837 \mathrm{MPa}$. At a high carbon content, hot rolled steel (wt.\%): 0.09C-0.29Mn-0.093Ti-0.26Mo-0.14V had a tensile strength of $1000 \mathrm{MPa}$ [23]. It should be noted that the concentrations of microalloying elements present in the steel under consideration are sufficient to bind the present interstitial elements- - , N. As a result, no cementite was detected in the steel microstructure. That means, there is a close analogy with IF steels with a solid solution free of interstitial atoms. The properties of the steels No. 6 and 8 are similar. 
In this case, a decrease in the $\mathrm{V}$ concentration in the metal of smelting No. 8 is compensated by the increased content of Ti and, to an insignificant degree, $\mathrm{Nb}$ and $\mathrm{Mn}$.

The maximum strength properties were obtained for rolled steel of smelting No. 4, characterized by a maximum Ti content and Mo microalloying. As follows from the results of TEM (Table 3) and thermodynamic calculation (Figure 5), high values of yield and tensile strength are the result of grain-boundary and dispersion hardening mechanisms due to the large number of complex nanoscale carbide precipitates $(\mathrm{Ti}, \mathrm{Nb}) \mathrm{C}$. The niobium content in this steel is small $(0.024 \mathrm{wt} . \%)$, and the result is in good agreement with the conclusions of the study of Ti-Mo microalloyed steels in [4] on the role of titanium. An increase in the concentration of this element promotes an increase in the number of carbide precipitates. At a higher carbon content (wt.\%): 0.08C-1.39Mn-0.21Mo-0.165Ti and a similar regime of thermo-deformation processing, the yield and ultimate strength of 770 and $840 \mathrm{MPa}$, respectively, were obtained. At the same time, the presence of molybdenum in the composition of the steel stimulates, as noted above, the acceleration of the nucleation of carbide (carbonitride) precipitates, but inhibits their growth. This is well illustrated by the data obtained in the present study. In particular, a simple increase in the Ti content in steel No. 3 led to a less increase in the strength characteristics of rolled products compared to the metal of smelting No. 2 than in the case of smelting No. 4 . On the other hand, the amount of carbide (carbonitride) precipitates formed is directly related to the concentration of Ti in the solid solution. Therefore, even if Mo is present in the steel composition, but Ti content is low, it is not possible to form a sufficiently large number of precipitates and to obtain high strength characteristics. This is evidenced by the relatively low yield and tensile strengths of rolled steel of smelting No. 5 . It is important that Ti remaining in the solid solution after binding at high temperatures of nitrogen and sulfur can participate in the formation of carbide (carbonitride) precipitates [31], while $\mathrm{S}$ and $\mathrm{N}$ content in steel of smelting No. 5 is quite high. As a result, only about $0.03 \mathrm{wt}$ \% Ti remains in the solid solution, which is not enough for the effective formation of a sufficiently large number of phase precipitates. A significant consumption of titanium to bind the nitrogen present, in many respects, also leads to a reduced level of strength properties of rolled steel of smelting No. 3. Thus, the presence of increased concentrations of nitrogen and sulfur in the composition of the steels under consideration is an unfavorable factor, since it leads to a decrease in the effectiveness of $\mathrm{Ti}$ and $\mathrm{Nb}$. The effect of phosphorus content is less significant, since the formation of complex phosphide precipitates in the general form of FeTiNbP, as well as phosphorus segregation along grain boundaries, for example, as in IF and IF-HS steels at the stage of recrystallization annealing, is of little significance in this case. Therefore, the low phosphorus content obtained in laboratory smelting steels is not a significant factor, since its increase to the level usually found in modern metallurgical practice of $0.006-0.010 \mathrm{wt} . \%$ will not change the indicators of the structural state and properties of steel.

It should be noted that $\mathrm{Ti}$ and $\mathrm{V}$ have the highest propensity for the formation of the most effective interphase carbide precipitates. These alloying metals have a small atomic diameter and, therefore, a greater diffusion mobility [32], which allows the implementation of the process at higher rates of $\gamma \rightarrow$ $\alpha$ transformation of steel. Moreover, Ti has a smaller atomic diameter, higher thermodynamic stability, and, hence, the higher driving force for the formation of carbide precipitates in steel. This, in particular, is indicated by the results of calculating the stability conditions for the carbide, nitride, and carbonitride phases of the considered steel elements $[30,33]$. The formation of this type of titanium precipitates occurs at incomparably higher temperatures than vanadium under other equivalent conditions. The noted circumstances correlate well with the results obtained. From the data of Tables 1 and 2, it can be seen that rolled products produced under equivalent conditions (steels No. 6 and 8) have higher strength characteristics with a lower titanium content compared with vanadium. The participation of niobium in the formation of interphase precipitates is greatly limited due to the significantly larger size and lower diffusion mobility of atoms despite the high thermodynamic stability of carbonitride phases comparable with titanium [30,32]. Values of the relative elongation of the studied rolled steels are quite close. However, steels, which containing titanium as the main microalloying element (having the highest concentration), in general, have slightly higher values than in the case of vanadium. Taking into 
account economic and cost indicators, the results obtained testify to the advantages of titanium-based microalloying systems in comparison with vanadium-based.

\section{Conclusions}

Thus, a study of the microstructure, phase precipitates, and mechanical properties of separately or jointly $\mathrm{V}, \mathrm{Nb}, \mathrm{Ti}$, and Mo microalloyed low-carbon hot-rolled steels of the ferritic class made it possible to establish the following special features. When they are cooled after rolling, even at a low cooling rate of $10-15^{\circ} \mathrm{C} / \mathrm{s}$, unlike Ti, Mo microalloyed steels, block ferrite is formed mainly. The shape of the blocks is closer to equiaxial, except for steel with a high content of microalloying components, where the blocks have an elongated shape. On the contrary, in low microalloyed steels, the fraction of block ferrite is only $\sim 20-35 \%$, and PF predominates, as in Ti-Mo steels. In the metal of all melts, the presence of cementite precipitates up to several microns in size was detected, except for steel with high Ti and V content.

The amount of austenitic carbide (carbonitride) precipitates in $\mathrm{Nb}$, Ti microalloyed steels is much smaller than in the case of complex $\mathrm{V}, \mathrm{Nb}, \mathrm{Ti}$, and Mo microalloying, except for steel with a low $\mathrm{V}, \mathrm{Nb}$, and Ti content. Their effect on the structural state and properties of steel is negligible. The presence of more efficient nanoscale interphase/mixed type precipitates was detected in all steels, except steel, characterized by low $\mathrm{V}, \mathrm{Nb}$, and Ti concentrations. In different areas of the metal, the ratio of volume fractions of interphase and austenitic precipitates can vary significantly. In those grains (blocks) where both types of precipitations are located, there are areas occupied exclusively by precipitations of one type or another. The noted circumstance shows that the formation of austenitic precipitates significantly reduces the potential of microalloying elements and prevents the formation of interphase precipitates. The data obtained by TEM methods on the number of various types of phase precipitates are confirmed by the results of a thermodynamic calculation of the temperature dependences of the equilibrium phase composition of steels.

The established special features of changes in the structural state and present phase precipitates correlate well with the obtained values of the mechanical properties. As in Ti-Mo microalloyed steels, the strength characteristics of rolled products enhance upon obtaining the microstructure of block ferrite and an increase in the number of nanoscale interphase and mixed type precipitates, the amount of which grows with increasing $\mathrm{V}, \mathrm{Nb}$, and $\mathrm{Ti}$ concentrations and the presence of Mo in the metal composition. In addition, the highest yield and tensile strengths were obtained for hot-rolled $\mathrm{Nb}, \mathrm{Ti}$, and Mo microalloyed steel with a significant titanium content of $0.17 \mathrm{wt} . \%$. It is shown that rolled products obtained under equivalent conditions have higher strength characteristics at a lower titanium content compared to vanadium. Values of the relative elongation of the studied rolled steels are quite close. However, for steels with the titanium-based microalloying system, slightly higher values are obtained than in the case of vanadium-based. Taking into account economic indicators, the obtained results testify to the advantages of using titanium-based microalloying systems for the investigated type of steels in comparison with vanadium-based.

Author Contributions: Conceptualization, A.Z. and A.K.; methodology, A.Z. and A.K.; software, A.K.; validation, A.Z. and S.D.; formal analysis, S.D.; investigation, A.K., N.A. and D.D.; writing-original draft preparation, N.A.; writing-review and editing, A.Z.; supervision, A.Z.; project administration, A.Z. All authors have read and agreed to the published version of the manuscript.

Funding: This research was supported by the grant of the Russian Science Foundation (Project No. 18-19-00639) and was performed at Bardin Central Research Institute of Ferrous Metallurgy.

Conflicts of Interest: The authors declare no conflict of interest.

\section{References}

1. Lesch, C.; Kwiaton, N.; Klose, F.B. Advanced high strength steels (AHSS) for automotive applications-Tailored properties by smart microstructural adjustments. Steel Res. Int. 2017, 88. [CrossRef]

2. Fonstein, N. Advanced High Strength Sheet Steels; Springer Science and Business Media LLC: Cham, Switzerland, 2015; pp. 3-14. 
3. Funakawa, Y.; Shiozaki, T.; Tomita, K.; Yamamoto, T.; Maeda, E. Development of High Strength Hot-Rolled Sheet Steel Consisting of Ferrite and Nanometer-Sized Carbides. ISIJ Int. 2004, 44, 1945-1951. [CrossRef]

4. Koldaev, A.V.; Zaitsev, A.I.; Krasnyanskaya, I.A.; D'yakonov, D.L. Study of the effect of composition and thermal deformation treatment on properties of ferritic steels microalloyed with titanium and niobium. Part 2. Phase precipitate characteristics. Metallurgist 2019, 63, 604-616.

5. Koldaev, A.V.; Zaitsev, A.I.; Krasnyanskaya, I.A.; D’Yakonov, D.L. Study of the Effect of Composition and Thermal Deformation Treatment on Properties of Ferritic Steels Microalloyed with Titanium and Niobium. Part 1. Microstructure Characteristics. Metallurgist 2019, 63, 487-495. [CrossRef]

6. Deng, X.; Fu, T.; Wang, Z.; Liu, G.; Wang, G.; Misra, R.D.K. Extending the boundaries of mechanical properties of Ti-Nb low-Carbon steel via combination of ultrafast cooling and deformation during austenite-to-Ferrite transformation. Met. Mater. Int. 2017, 23, 175-183. [CrossRef]

7. Rijkenberg, A.; Blowey, A.; Bellina, P.; Wooffindin, C. Advanced high stretch-flange formability steels for chassis \& suspension applications. In Proceedings of the SCT2014 (4th International Conference on Steels in Cars and Trucks), Braunschweig, Germany, 15-19 June 2014; pp. 426-433.

8. Funakawa, Y.; Seto, K. Coarsening Behavior of Nanometer-Sized Carbides in Hot-Rolled High Strength Sheet Steel. Mater. Sci. Forum. 2007, 539, 4813-4818. [CrossRef]

9. Jia, Z.; Misra, R.; Omalley, R.; Jansto, S. Fine-Scale precipitation and mechanical properties of thin slab processed titanium-niobium bearing high strength steels. Mater. Sci. Eng. A 2011, 528, 7077-7083. [CrossRef]

10. Bu, F.; Wang, X.; Yang, S.; Shang, C.; Misra, D. Contribution of interphase precipitation on yield strength in thermomechanically simulated Ti-Nb and Ti-Nb-Mo microalloyed steels. Mater. Sci. Eng. A 2015, 620, 22-29. [CrossRef]

11. Chen, C.; Yen, H.-W.; Kao, F.; Li, W.; Huang, C.; Yang, J.-R.; Wang, S. Precipitation hardening of high-Strength low-Alloy steels by nanometer-Sized carbides. Mater. Sci. Eng. A 2009, 499, 162-166. [CrossRef]

12. Seto, K.; Funakawa, Y.; Kaneko, S. Hot Rolling High Strength Steels for Suspension and Chassis Parts "NANOHITEN" and "BTH Steels". JFE Tech. Rep. 2007, 10, 19-25.

13. Mao, X.; Huo, X.; Sun, X.; Chai, Y. Strengthening mechanisms of a new 700MPa hot rolled Ti-Microalloyed steel produced by compact strip production. J. Mater. Process. Technol. 2010, 210, 1660-1666. [CrossRef]

14. Frisk, K.; Borggren, U. Precipitation in Microalloyed Steel by Model Alloy Experiments and Thermodynamic Calculations. Met. Mater. Trans. A 2016, 47, 4806-4817. [CrossRef]

15. Kamikawa, N.; Sato, K.; Miyamoto, G.; Murayama, M.; Sekido, N.; Tsuzaki, K.; Furuhara, T. Stress-Strain behavior of ferrite and bainite with nano-Precipitation in low carbon steels. Acta Mater. 2015, 83, 383-396. [CrossRef]

16. Shaposhnikov, N.G.; Koldaev, A.V.; Zaitsev, A.I.; Rodionova, I.G.; D'yakonov, D.L.; Arutyunyan, N.A. Regularities of titanium carbide precipitation in low carbon Ti-Mo-Microalloyed high strength steels. Metallurgist 2016, 60, 810-816. [CrossRef]

17. Zaitsev, A.I.; Rodionova, I.G.A.V.; Arutyunyan, N.A.; Dunaev, S.F. Investigation of regularities of phase precipitation formation, structural state, and properties of microalloyed low-carbon steels of the ferritic class. Metallurgist 2020, 64. in press.

18. Khalid, F.A.; Edmonds, D.V. Interphase precipitation in microalloyed engineering steels and model alloy. Mater. Sci. Eng. 1993, 9, 384-396. [CrossRef]

19. Shaposhnikov, N.G.; Rodionova, I.A.; Pavlov, A.A. Thermodynamic Development of Austenite-Martensite Class Corrosion-Resistant Steels Intended for a Bimetal Cladding Layer. Metallurgist 2016, 59, 1195-1200. [CrossRef]

20. Chen, C.Y.; Chen, C.C.; Yang, J.-R. Microstructure characterization of nanometer carbides heterogeneous precipitation in Ti-Nb and Ti-Nb-Mo steel. Mater. Charact. 2014, 88, 69-79. [CrossRef]

21. Xinjun, $\mathrm{S}$. The roles and applications of molybdenum element in low alloy steels. In Proceedings of the International Seminar on Applications Mo in Steels, Beijing, China, 27-28 June 2010; pp. 60-74.

22. Wang, Z.Q.; Zhang, H.; Guo, C.; Liu, W.; Yang, Z.; Sun, X.; Zhang, Z.; Jiang, F. Effect of molybdenum addition on the precipitation of carbides in the austenite matrix of titanium micro-alloyed steels. J. Mater. Sci. 2016, 51, 4996-5007. [CrossRef]

23. Zhang, K.; Li, Z.-D.; Sun, X.-J.; Yong, Q.-L.; Yang, J.-W.; Li, Y.-M.; Zhao, P.-L. Development of Ti-V-Mo Complex Microalloyed Hot-Rolled 900-MPa-Grade High-Strength Steel. Acta Met. Sin. Engl. Lett. 2015, 28, 641-648. [CrossRef] 
24. Kamikawa, N.; Abe, Y.; Miyamoto, G.; Funakawa, Y.; Furuhara, T. Tensile Behavior of Ti,Mo-Added Low Carbon Steels with Interphase Precipitation. ISIJ Int. 2014, 54, 212-221. [CrossRef]

25. Zhang, Z.; Yong, Q.; Sun, X.; Li, Z.; Wang, Z.; Zhou, S.; Wang, G. Effect of Mo addition on the precipitation behavior of carbide in Nb-bearing HSLA steel. In Proceedings of the Conference HSLA Steels 2015, Microalloying 2015 \& Offshore Engineering Steels 2015, Hangzhou, China, 11-13 November 2015; pp. 203-210.

26. Jang, J.H.; Heo, Y.-U.; Lee, C.-H.; Bhadeshia, H.; Suh, D.-W. Interphase precipitation in Ti-Nb and Ti-Nb-Mo bearing steel. Mater. Sci. Technol. 2013, 29, 309-313. [CrossRef]

27. Lee, W.; Hong, S.; Park, C.; Kim, K.; Park, S. Influence of Mo on precipitation hardening in hot rolled HSLA steels containing Nb. Scr. Mater. 2000, 43, 319-324. [CrossRef]

28. Zaitsev, A.I.; Koldaev, A.V.; Krasnyanskaya, I.A.; Dunaev, S. Study of Features of Phase Precipitate Formation, Structural State, and Properties of Nb, V-Microalloyed Low Carbon Ferritic Steels. Metallurgist 2020, 63, 1033-1042. [CrossRef]

29. Hutchinson, C.R.; Zurob, H.; Sinclair, C.; Brechet, Y. The comparative effectiveness of Nb solute and $\mathrm{NbC}$ precipitates at impeding grain-boundary motion in $\mathrm{Nb}$ steels. Scr. Mater. 2008, 59, 635-637. [CrossRef]

30. Lagneborg, R.; Siwecki, T.; Zajac, S.; Hutchinson, B. The role of vanadium in microalloyed steels. Scand. J. Metall. 1999, 28, 1-86.

31. Zaitsev, A.I.; Rodionova, I.G.; Koldaev, A.V.; Arutyunyan, N.A. Effect of composition and processing parameters on the microstructure and mechanical properties of cold-Rolled and galvanized roll products from IF steels. Metallurgist 2020, 64, 136-144. [CrossRef]

32. Oono, N.; Nitta, H.; Iijima, Y. Diffusion of niobium in $\alpha$-Iron. Mater. Trans. JIM 2003, 44, 2078-2083. [CrossRef]

33. Zaitsev, A.I.; Koldaev, A.V.; Gladchenkova, Y.S.; Shaposhnikov, N.G.; Dunaev, S.F. Structural State Evolution and Rolled Product Properties in Relation to Treatment Regime of Model Steels for Hot Stamping. 1. Hot-Rolled Product. Metallurgist 2016, 60, 274-280. [CrossRef]

(C) 2020 by the authors. Licensee MDPI, Basel, Switzerland. This article is an open access article distributed under the terms and conditions of the Creative Commons Attribution (CC BY) license (http://creativecommons.org/licenses/by/4.0/). 